\title{
Uptake and Exportation of Micronutrients by Transgenic Cultivars of Maize Under No-tillage in the Brazilian Cerrado
}

\author{
Aarón Martínez Gutiérrez ${ }^{1}$, Álvaro Vilela De Resende ${ }^{2}$, Carine Gregorio Machado Silva ${ }^{3}$, \\ Denize Carvalho Martins ${ }^{1}$, Eduardo De Paula Simão ${ }^{1}$, Silvino Guimarães Moreira ${ }^{3}$ \\ $\&$ Jose Paulo da Costa Ferreira ${ }^{4}$ \\ ${ }^{1}$ Department of Plant Science, Federal University of Viçosa, Viçosa, Brazi \\ ${ }^{2}$ Embrapa Maize and Sorghum, Sete Lagoas, Brazil \\ ${ }^{3}$ Department of Agriculture, Federal University of Lavras, Brazil \\ ${ }^{4}$ Federal University of São João Del-Rei, Brazil \\ Correspondence: Aarón Martínez Gutiérrez, Department of Plant Science, Federal University of Viçosa, Viçosa, \\ Brazil. E-mail: aaron_0715@hotmail.com
}

Received: May 8, 2018

doi:10.5539/jas.v10n9p304
Accepted: June 27, 2018 Online Published: August 15, 2018

URL: https://doi.org/10.5539/jas.v10n9p304

\begin{abstract}
Introducing cultivars of high productive potential with adequate agronomic management has contributed to the increase of maize yield in Brazil. This study aimed to characterize the extraction and exportation of micronutrients by modern maize hybrids grown in no-tillage system in the Cerrado region (Brazilian Savannah) with two fertilization levels. We established two crop environments with differentiated levels of soil fertilization, use of products for seed treatment and leaf fertilization, in which four transgenic hybrids were grown. For each environment, we used an experimental design of randomized blocks with four replicates. There were eleven plant samplings during the crop cycle to quantify dry mass production and $\mathrm{Cu}, \mathrm{Fe}, \mathrm{Mn}$ and $\mathrm{Zn}$ extraction. Micronutrient uptake is increased when a hybrid with higher potential for biomass production grows in an environment with greater supply of nutrients. Uptake persists throughout the maize cycle, including during the final stages of the reproductive phase, showing late demand for the crop. On average, after tasseling, about 39, 50,42 , and $49 \%$ of the total $\mathrm{Cu}, \mathrm{Fe}, \mathrm{Mn}$ and $\mathrm{Zn}$ absorption still occurs, respectively. Total uptake of $\mathrm{Cu}, \mathrm{Fe}, \mathrm{Mn}$ and $\mathrm{Zn}$ are, respectively, around 8, 199, 58 and $40 \mathrm{~g}$ to produce a tonne of grain, from which $23,5,8$, and $42 \%$ are exported by the harvest. Micronutrient uptake and exportation rates for the studied transgenic hybrids are lower than the ones previously reported in Brazil and in works abroad.
\end{abstract}

Keywords: absorption march, high yield, nutritional requirements, Zea mays $\mathrm{L}$.

\section{Introduction}

Features of nutrients, quantity and the most adequate time for their supply are information necessary for plant nutritional balance, in order to allow maximum expression of its genetic potential of production. Understanding the dynamics of nutrient absorption in phenological stages of maize allows determining the potential response to fertilization and the periods of higher nutritional requirement (Ciampitti \& Vyn, 2014).

Absorption curves during the cycle reflect the amount of nutrients necessary to the plant; however, it does not indicate directly the amount of fertilization, considering the efficiency of fertilizer utilization is essential, varying according to the climatic conditions, environments and agronomy management (Castoldi et al., 2009).

Although Brazil has a notable progress in research on soil fertility and plant nutrition in recent decades, there is a lack of up-to-date information on the nutritional requirements of maize, especially for micronutrient requirements. There is little recent data on absorption march of nutrients and most publications focus mainly on macronutrients, which are most in demand by the crop. In general, Brazilian studies on absorption march are from decades ago, with different cultivars from those currently available, based on yield levels smaller than the achieved in the best tillages and in crops with conventional soil preparation.

Micronutrient extraction and exportation rates for maize genotypes vary substantially due to genetic variability, which provides distinct behavior among cultivars (Ferreira, 2009). In addition, exportation standards of maize 
nutrient are directly related to the productivity (Coelho \& França, 1995; Coelho \& Resende, 2008; Bender et al., 2013), which still depends on the soil availability levels of different field environments (Padilha et al., 2015).

Andrade et al. (1795b) carried out the main pioneer study in Brazil. They evaluated micronutrient extraction by maize cultivars, observing the following variation (in $\mathrm{g} \mathrm{ha}^{-1}$ ): 103 to $146 \mathrm{Cu} ; 1,334$ to $1,815 \mathrm{Fe}$; 496 to $720 \mathrm{Mn}$; and 294 to $335 \mathrm{Zn}$. Coelho and França (1995) report extraction of 110.9; 2,100; 340 and $400 \mathrm{~g} \mathrm{ha}^{-1} \mathrm{Cu}, \mathrm{Fe}, \mathrm{Mn}$ and $\mathrm{Zn}$, respectively. In the United States, considering the average of six cultivars and two sites, Bender et al. (2013) observed extraction of $100 ; 1,400 ; 500$ and $500 \mathrm{~g} \mathrm{ha}^{-1} \mathrm{Cu}, \mathrm{Fe}, \mathrm{Mn}$ and $\mathrm{Zn}$, respectively.

This context justifies researches that study modern cultivars, identifying the minimum amounts of micronutrients to be replaced for maintaining the productive capacity of the soil over time. Thus, this study aimed to determine the extraction and exportantion of copper $(\mathrm{Cu})$, iron $(\mathrm{Fe})$, manganese $(\mathrm{Mn})$ and zinc $(\mathrm{Zn})$ by transgenic hybrids, cultivated under two fertilization levels in a no-tillage Oxisol system, in the Brazilian Cerrado.

\section{Material and Methods}

This study occurred in the 2014/2015 crop season, in the experimental area of Embrapa Maize and Sorghum, S latitude $19^{\circ} 28^{\prime} 30^{\prime \prime}$, W longitude $44^{\circ} 15^{\prime} 08^{\prime \prime}, 732 \mathrm{~m}$ altitude, in Sete Lagoas, State of Minas Gerais, Brazil. Climate, according to Köppen, is Aw, typical of Savannah, with dry winter and average air temperature in the coldest month above $18^{\circ} \mathrm{C}$. The experimental area consists of a dystrophic Red Latosol (Embrapa, 2013), with a very clayey texture $\left(660 \mathrm{~g} \mathrm{~kg}^{-1}\right.$ clay).

In 2012, the area was divided into two environments, under medium or high technological investment in fertilization (Padilha et al., 2015). In November 2014, before assembling the experiment for the study, $2 \mathrm{t} \mathrm{ha}^{-1}$ dolomitic limestone, $1 \mathrm{tha}^{-1}$ gypsum and $200 \mathrm{~kg} \mathrm{ha}^{-1}$ mixture of 3:1 potassium chloride and FTE BR 12 were spread in the environment with high investment, in order to provide soil fertility differential conditions.

On December 17, 2014, four transgenic maize hybrids were sown (AG 8088 PRO X, DKB 310 PRO 2, DKB $390 \mathrm{PRO}$ and $\mathrm{P} 30 \mathrm{~F} 53 \mathrm{YH}$ ) in high and medium fertilization environments using plot spacing seeder of $0.5 \mathrm{~m}$ between rows and 70,000 seeds per hectare. The cultivation occurred with complementary irrigation managed under no-tillage system.

In each environment, the experimental design took place in randomized blocks with four replicates. Plots consisted of four $6 \mathrm{~m}$ rows in length; the two central rows with one-meter border at the ends were the useful area $\left(4 \mathrm{~m}^{2}\right)$. There were duplicated plots of each treatment in order to collect plants along the cycle to determine the micronutrient absorption march, and to evaluate the grain yield after physiological maturation.

For the environment with high investment, seeds were treated with the insecticide $\mathrm{Cropstar}^{\circledR}$ (imidacloprid + thiodicarb, $\left.350 \mathrm{~mL} 100 \mathrm{~kg}^{-1}\right)$, plus fertilizer Biozyme ${ }^{\circledR}\left(600 \mathrm{~mL} 100 \mathrm{~kg}^{-1}\right)$, consisting of $1.73 \% \mathrm{~N} ; 5 \% \mathrm{~K}_{2} \mathrm{O}$; $0.08 \% \mathrm{~B} ; 0.49 \% \mathrm{Fe} ; 2.1 \% \mathrm{~S} ; 2.45 \% \mathrm{Zn} ; 1.0 \% \mathrm{Mn} ; 3.5 \% \mathrm{Co}$. For the environment with medium investment, the seeds received insecticide only. In the sowing fertilization, we used 500 and $340 \mathrm{~kg} \mathrm{ha}^{-1} \mathrm{NPK}$ formula 08-28-16 $+0.3 \% \mathrm{~B}$, corresponding to high and medium investment, respectively.

Twenty days after sowing (DAS), when the plants reached the phenological stage V4 (Ritchie et al., 2003), a cover fertilization was developed in both environments, with $90 \mathrm{~kg} \mathrm{ha}^{-1} \mathrm{~N}\left(200 \mathrm{~kg} \mathrm{ha}^{-1}\right.$ de urea). In the high-investment environment, two more cover fertilizations were performed, providing $70 \mathrm{~kg} \mathrm{ha}^{-1} \mathrm{~N}$ and $\mathrm{K}_{2} \mathrm{O}$ (350 kg ha ${ }^{-1}$ NPK 20-00-20) at 27 days after sowing, at the phonological V5 stage; and $40 \mathrm{~kg} \mathrm{ha}^{-1} \mathrm{~N}+44 \mathrm{~kg} \mathrm{ha}^{-1}$ $\mathrm{S}$ (200 kg ha ${ }^{-1}$ ammonium sulphate) 33 days after sowing, at V7 stage. Finally, in the V7 stage, foliar fertilization took place in the high-investment environment with a mixture of Biozyme ${ }^{\circledR}\left(2 \mathrm{~L} \mathrm{ha}^{-1}\right)$, monoammonium phosphate - MAP $\left(2.5 \mathrm{~kg} \mathrm{ha}^{-1}\right)$ and calcium nitrate $\left.1.5 \mathrm{~kg} \mathrm{ha}^{-1}\right)$, using coastal sprayer.

At 20 DAS, soil sampling took place to characterize the fertility conditions for maize cultivation, at a $0-20 \mathrm{~cm}$ depth (Table 1), following analytical methodologies using the Mehlich 1 extractant for $\mathrm{Cu}, \mathrm{Fe}, \mathrm{Mn}$ and $\mathrm{Zn}$, and hot water for B, as described by Silva (2009). Herbicides and insecticides were used in phytosanitary treatments, according to technical criteria for the control of weeds and caterpillars. 
Table 1. Soil fertility conditions in environments with medium and high fertilization investment, at 0-20 cm depth

\begin{tabular}{|c|c|c|c|c|c|c|c|c|c|c|c|c|}
\hline Investment & $\mathrm{pH}$ & MO & $\mathrm{P}^{1}$ & $\mathrm{~K}$ & $\mathrm{~S}$ & $\mathrm{Ca}$ & $\mathrm{Mg}$ & $\mathrm{Al}^{3+}$ & $\mathrm{H}+\mathrm{Al}$ & CTC & $\mathrm{V}^{2}$ & $\mathrm{~m}^{3}$ \\
\hline & Water & dag $\mathrm{kg}^{-1}$ & \multicolumn{3}{|c|}{----- $\mathrm{mg} \mathrm{dm}^{-3}$----- } & \multicolumn{5}{|c|}{---------------- $\mathrm{cmol}_{\mathrm{c}} \mathrm{dm}^{-3}$-------------- } & \multicolumn{2}{|c|}{---- \% ---- } \\
\hline Medium & 6.1 & 4.1 & 14 & 54 & 4 & 6.2 & 1.0 & 0 & 5.6 & 13 & 57 & 0 \\
\hline High & 6.0 & 3.9 & 22 & 159 & 15 & 5.7 & 1.2 & 0 & 6.8 & 14 & 52 & 0 \\
\hline
\end{tabular}

Note. ${ }^{1}$ Mehlich 1 extractant. ${ }^{2}$ Base saturation. ${ }^{3}$ Aluminum saturation. Micronutrients $\left(\mathrm{mg} \mathrm{dm}^{-3}\right)$ : Medium investment: $\mathrm{B}=1.1 ; \mathrm{Cu}=0.9 ; \mathrm{Fe}=28 ; \mathrm{Mn}=54.3 ; \mathrm{Zn}=3.4 ;$ High investment: $\mathrm{B}=1.8 ; \mathrm{Cu}=0.5 ; \mathrm{Fe}=19 ; \mathrm{Mn}=$ 9.2; $\mathrm{Zn}=3.8 ;$ Granulometric analysis $\left(\mathrm{g} \mathrm{kg}^{-1}\right):$ sand $=130 ;$ silt $=210$; and clay $=660$.

To characterize micronutrient absorption march, eleven plant samplings were taken from the useful area of the plots. The first collection occurred in the V4 stage, with four plants being cutted from each plot. In the other collections, two representative plants were obtained at the following phenological stages defined by Ritchie et al. (2003): V5, V7, V9, V12, VT, R1, R2, R3, R5 and R6. Plants were cutted close to the soil and, when appropriate, fragmented into stem, leaf, straw + cob and grains. Samples from the different parts of the plant were oven dried at $65^{\circ} \mathrm{C}$ until constant weight. Afterwards, we weighed and grinded them for $\mathrm{Cu}, \mathrm{Fe}, \mathrm{Mn}$ and $\mathrm{Zn}$ determinations, according to the methodologies described in Silva (2009).

Nutrient accumulation in the different phenological stages was calculated by multiplying the content obtained in the laboratory analysis by the respective dry mass of each plant compartment. The values were extrapolated to a stand of 70,000 plants per hectare, a population commonly used in summer crops aiming high yields.

We harvested the useful area from the plots to perform grain yield evaluation after physiological maturation. Productivity corrected to $13 \%$ humidity was used to calculate the micronutrient accumulation in the grains at the end of the maize cycle, corresponding to the quantities exported with the harvest.

For each phenological stage, the variables were submitted to joint analysis of variance, in order to verify the existence of interaction between hybrids and fertilization investment environments. Grouping test of Scott-Knott averages $5 \%$ probability compared treatments for dry mass production and micronutrient accumulation in different phenological stages as well as grain yield, with the aid of statistical program SISVAR (Ferreira, 2011).

\section{Results and Discussion}

For the total dry mass at physiological maturation (stage R6), there was a significant effect of investment environments on fertilization and hybrids. On average, the dry mass accumulation up to this stage was approximately $25,627 \mathrm{~kg} \mathrm{ha}^{-1}$ (Table 2) with an order partition of 10, 28, 16 and $43 \%$ between the leaf, stem, straw + cob and grain compartments, respectively (Figure 1).

Dry mass production was statistically different between the high and medium investment environments (Table 2), with a difference of $10.8 \%$, showing a considerable response due to the improvement of soil fertility by higher fertilization, which should have an impact also in the quantities of micronutrients. In both environments, accumulation of dry mass until flowering (stage R1, 64 DAS) reached a little less than half (45.9\%) of the total (Figure 1), becoming more intense later, so that in the 40 following days (stage R5, 104 DAS), the crop reached $95 \%$ of total dry mass production. 
Table 2. Total dry mass of shoot in physiological maturation $\left(\mathrm{kg} \mathrm{ha}^{-1}\right)$ and grain yield $\left(\mathrm{kg} \mathrm{ha}^{-1}\right)$ by maize as a function of hybrids and environments with high and medium investment in fertilization

\begin{tabular}{|c|c|c|c|c|c|c|}
\hline \multirow{3}{*}{ Hybrids } & \multirow{2}{*}{\multicolumn{2}{|c|}{$\begin{array}{c}\text { Total dry mass } \\
\text { Investment }\end{array}$}} & \multirow{3}{*}{$\begin{array}{l}\text { Average of } \\
\text { hybrids }\end{array}$} & \multirow{2}{*}{\multicolumn{2}{|c|}{$\begin{array}{c}\text { Grain yield } \\
\text { Investment }\end{array}$}} & \multirow{3}{*}{$\begin{array}{l}\text { Average o } \\
\text { hybrids }\end{array}$} \\
\hline & & & & & & \\
\hline & High & Medium & & High & Medium & \\
\hline AG 8088 PRO X & 24.353 & 22.758 & $23.555 \mathrm{~b}$ & 10.840 & 10.727 & $10.784 \mathrm{~b}$ \\
\hline DKB 310 PRO2 & 34.148 & 29.971 & $32.059 \mathrm{a}$ & 13.993 & 12.446 & $13.219 \mathrm{a}$ \\
\hline DKB 390 PRO & 24.048 & 22.811 & $23.429 \mathrm{~b}$ & 10.577 & 11.009 & $10.793 \mathrm{~b}$ \\
\hline P 30F53 HY & 25.833 & 21.099 & $23.465 \mathrm{~b}$ & 9.805 & 8.794 & $9.299 \mathrm{c}$ \\
\hline Average of environments & $27.095 \mathrm{~A}$ & $24.159 \mathrm{~B}$ & & $11.304 \mathrm{~A}$ & $10.744 \mathrm{~A}$ & \\
\hline General Average & \multicolumn{3}{|l|}{25.627} & \multicolumn{2}{|l|}{11.024} & \\
\hline $\mathrm{CV}(\%)$ & \multicolumn{3}{|l|}{8.69} & \multicolumn{2}{|l|}{7.34} & \\
\hline
\end{tabular}

Note. For each variable, averages followed by the same lowercase letter in the column and upper case in the row do not differ by Scott-Knott test at $5 \%$ probability.
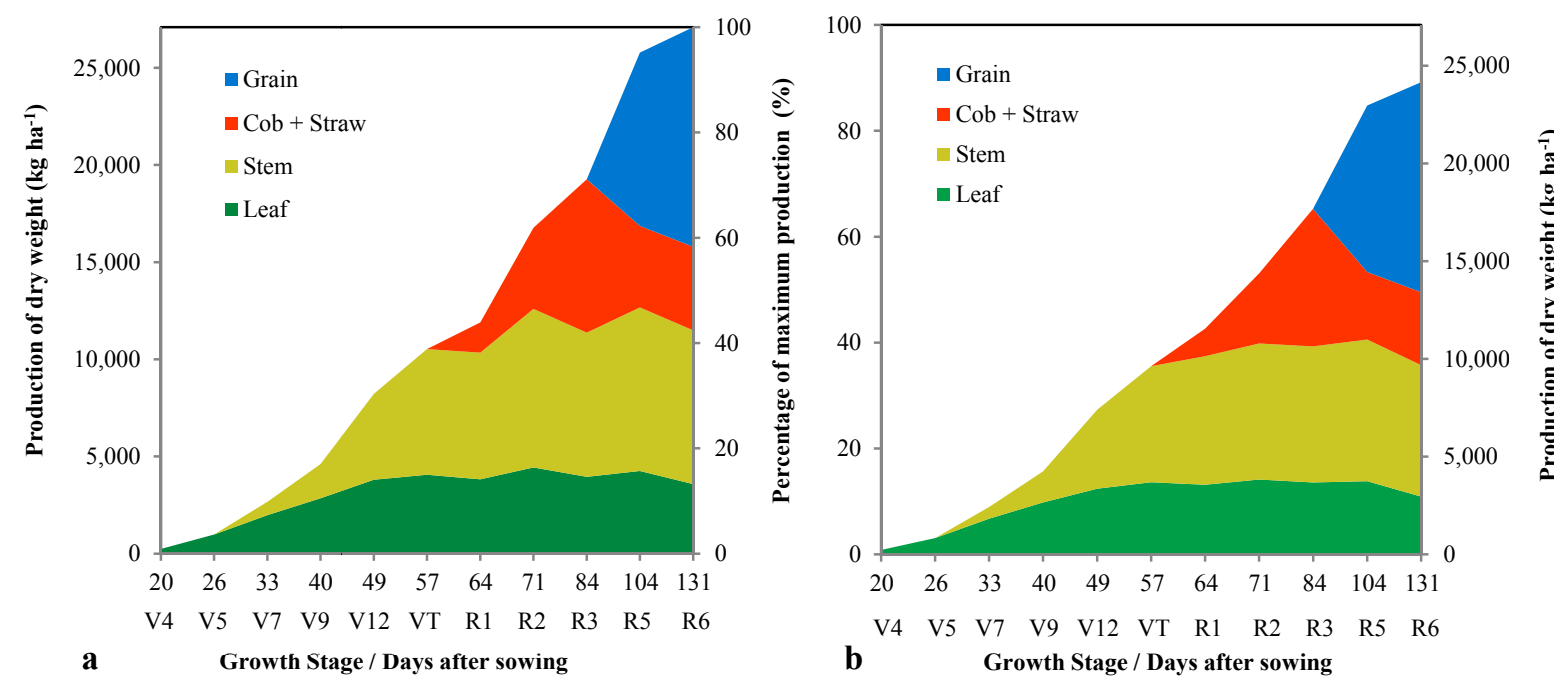

Figure 1. Dry mass production of shoot over the maize cycle grown in environments with high (a) and medium

(b) investment in fertilization. Average of four hybrids

Hybrids showed a significant difference of dry mass production in the environments average (Table 2), varying from 23,429 to $32,059 \mathrm{~kg} \mathrm{ha}^{-1}$, especially the hybrid DKB 310 with the highest dry mass at the end of the cycle and exceeded the over grain production.

Andrade et al. (1975a) found differences between cultivars in relation to the amounts of total dry mass and accumulated nutrients. However, they suggested that these variations would not necessarily translate into an increase in grain production. The improvement in grain yield of maize along time have been associated with an increase in dry mass production (Lorenz et al., 2010), and this relationship would be the driving force for greater uptake and remobilization of nutrients in the modern hybrids (Bender et al., 2013).

In general, dry mass production results in this study were higher than those reported in previous studies (Andrade et al., 1975a; Vasconcellos et al., 1983; Hiroce et al., 1989; Duarte, 2003), assessing absorption of nutrients by maize in Brazil and are close to those reported by Bender et al. (2013) in the USA. They evaluated six transgenic hybrids at two sites, obtaining a mean yield of $23,000 \mathrm{~kg} \mathrm{ha}^{-1}$ dry mass in R6. Thus, the tendency of greater capacity for dry mass accumulation is compatible with nowadays crops of high productive potential.

\subsection{Uptake and Exportation of Micronutrients}

Significant effects of hybrids and fertilizer investment environments were observed on $\mathrm{Cu}$ extraction by maize, markedly from the VT stage. However, these factors did not interact. DKB 310 hybrid showed higher $\mathrm{Cu}$ 
extraction capacity compared to the others, totaling $107.5 \mathrm{~g} \mathrm{ha}^{-1}$, a difference of $43 \%$ in relation to the lowest average (AG 8088), which is in agreement with its high potential for dry mass and grain production (Table 2).

The highest $\mathrm{Cu}$ extraction from the environment with high investment (Table 3) is probably due to the higher fertilization level that has been adopted over time, which intensifies maize development. Thus, greater accumulation of dry mass is expected to have direct reflection in the extraction of nutrients available in that environment.

Maximum extraction of this micronutrient was only completed in the physiological maturation, corresponding to 98 and $73 \mathrm{~g} \mathrm{ha}^{-1}$ in the high and medium fertilization environments, respectively (Table 3 and Figure 2). On average, up to $61.5 \%$ of the maximum accumulation was observed up to the bolting stage (VT), showing that a considerable part of $\mathrm{Cu}$ absorption occurs later, after crop anthesis.

Table 3. Micronutrient uptake $\left(\mathrm{g} \mathrm{ha}^{-1}\right)$ in different phenological stages of maize grown in environments with high and medium fertilization investment

\begin{tabular}{|c|c|c|c|c|c|c|c|c|}
\hline \multirow{3}{*}{ Phenological stage } & \multirow{2}{*}{\multicolumn{2}{|c|}{$\frac{\text { Copper }}{\text { Investment }}$}} & \multirow{2}{*}{\multicolumn{2}{|c|}{$\frac{\text { Iron }}{\text { Investment }}$}} & \multirow{2}{*}{\multicolumn{2}{|c|}{$\begin{array}{c}\text { Manganese } \\
\text { Investment }\end{array}$}} & \multirow{2}{*}{\multicolumn{2}{|c|}{$\frac{\text { Zinc }}{\text { Investment }}$}} \\
\hline & & & & & & & & \\
\hline & High & Medium & High & Medium & High & Medium & High & Medium \\
\hline V4 & $4 \mathrm{a}$ & $3 a$ & $448 \mathrm{a}$ & $441 \mathrm{a}$ & $14 \mathrm{a}$ & $12 \mathrm{a}$ & $12 \mathrm{a}$ & $11 \mathrm{~b}$ \\
\hline V5 & $12 \mathrm{a}$ & $10 \mathrm{a}$ & $446 \mathrm{a}$ & $344 \mathrm{~b}$ & $44 \mathrm{a}$ & $36 \mathrm{~b}$ & $41 \mathrm{a}$ & $33 \mathrm{~b}$ \\
\hline V7 & $21 \mathrm{a}$ & $19 \mathrm{~b}$ & $567 \mathrm{a}$ & $382 \mathrm{~b}$ & $128 \mathrm{a}$ & $105 \mathrm{~b}$ & $119 \mathrm{a}$ & $95 \mathrm{~b}$ \\
\hline V9 & $38 \mathrm{a}$ & $35 \mathrm{a}$ & $840 \mathrm{a}$ & $733 \mathrm{a}$ & $237 \mathrm{a}$ & $195 \mathrm{~b}$ & $155 \mathrm{a}$ & $103 \mathrm{~b}$ \\
\hline V12 & $56 \mathrm{a}$ & $44 \mathrm{a}$ & $1.189 \mathrm{a}$ & $978 \mathrm{a}$ & $382 \mathrm{a}$ & $283 \mathrm{~b}$ & $226 \mathrm{a}$ & $158 \mathrm{~b}$ \\
\hline VT & $58 \mathrm{a}$ & $47 \mathrm{~b}$ & $1.212 \mathrm{a}$ & $988 \mathrm{a}$ & $427 \mathrm{a}$ & $299 \mathrm{~b}$ & $262 \mathrm{a}$ & $190 \mathrm{~b}$ \\
\hline R1 & $59 \mathrm{a}$ & $47 \mathrm{~b}$ & $1.245 \mathrm{a}$ & $991 \mathrm{a}$ & $432 \mathrm{a}$ & $301 \mathrm{~b}$ & $279 a$ & $195 \mathrm{~b}$ \\
\hline R2 & $80 \mathrm{a}$ & $58 \mathrm{~b}$ & $1.529 \mathrm{a}$ & $1.208 \mathrm{~b}$ & $627 \mathrm{a}$ & $404 \mathrm{~b}$ & $387 \mathrm{a}$ & $259 \mathrm{~b}$ \\
\hline R3 & $79 \mathrm{a}$ & $59 \mathrm{~b}$ & $1.531 \mathrm{a}$ & $1.433 \mathrm{a}$ & $631 \mathrm{a}$ & $426 \mathrm{~b}$ & $428 \mathrm{a}$ & $303 \mathrm{~b}$ \\
\hline R5 & $95 \mathrm{a}$ & $70 \mathrm{~b}$ & $2.222 \mathrm{a}$ & $1.855 \mathrm{a}$ & $764 \mathrm{a}$ & $496 \mathrm{~b}$ & $484 \mathrm{a}$ & $393 \mathrm{~b}$ \\
\hline R6 & $98 \mathrm{a}$ & $73 \mathrm{~b}$ & $2.513 \mathrm{a}$ & $1.880 \mathrm{~b}$ & $778 \mathrm{a}$ & $500 \mathrm{~b}$ & $486 \mathrm{a}$ & $396 \mathrm{~b}$ \\
\hline
\end{tabular}

Note. For each variable, averages followed by the same letter in the row do not differ by Scott-Knott test at $5 \%$ probability.

These results are in agreement with Bender (2013), which reported that in the period before flowering only half of the total $\mathrm{Cu}$ accumulation has occurred. Maximum $\mathrm{Cu}$ extraction point determined by Andrade et al. (1975b) was between 101 and 108 days after emergence, and Borges et al. (2009) at 102 days after emergence. Confirmation of $\mathrm{Cu}$ extraction pattern extending to the end of the cycle indicates that, regardless of the hybrid used and the growing environment, ensuring conditions for satisfactory supply of this micronutrient, also during the grain filling stage of the crop, are important. 

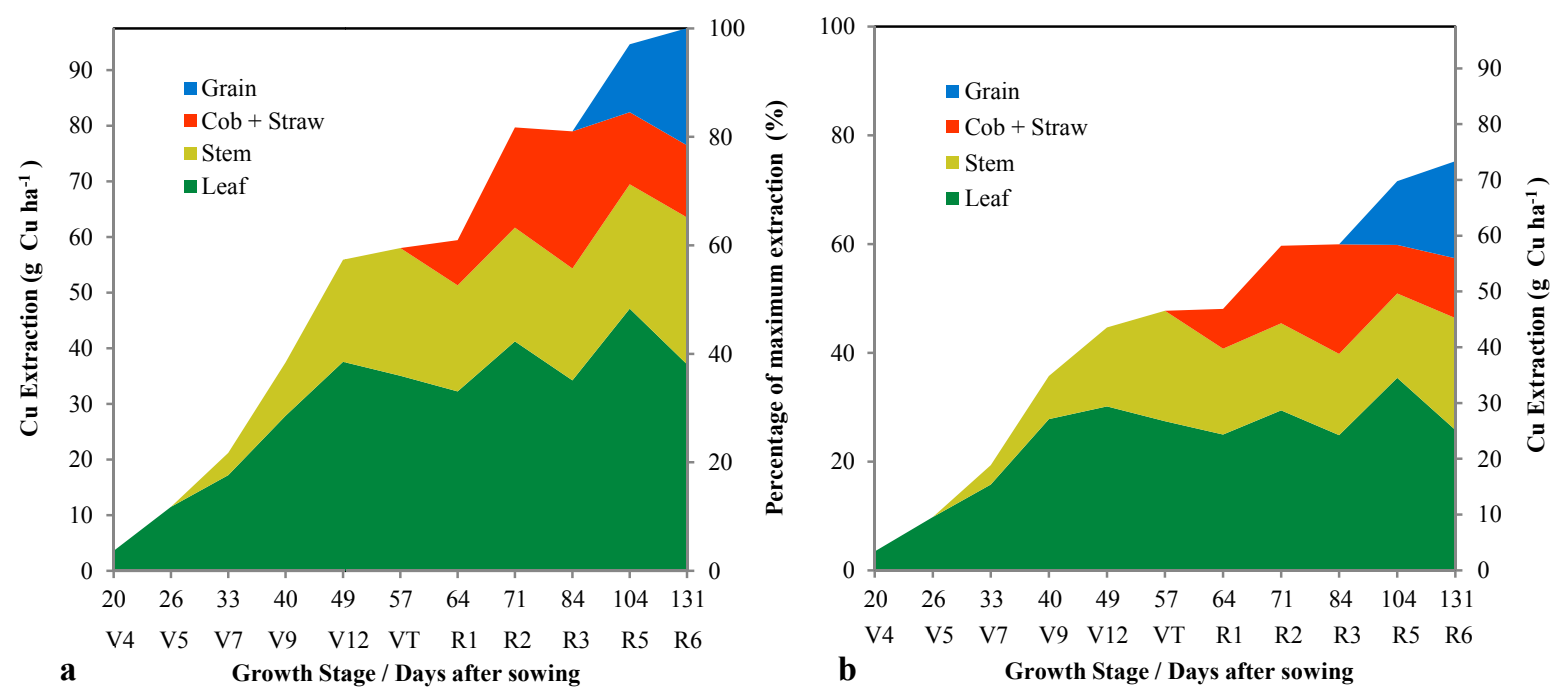

Figure 2. Copper uptake during maize cycle grown in environments with high (a) and medium (b) investment in fertilization. Average of four hybrids

There is a relatively even division of $\mathrm{Cu}$ distribution between plant organs, without major changes along the cycle (Figure 2). On average, copper partition accumulated in R6 (physiological maturation) was 36, 27, 14 and $26 \%$ among leaf, stem, straw + cob and grains components, respectively. In this study, we needed an average of $8 \mathrm{~g} \mathrm{Cu}$ to produce a tonne of maize grains. This corresponds to that reported by Ciampitti \& Vyn (2013) when evaluating two hybrids at two sites in the USA, with an average yield of $10.0 \mathrm{t} \mathrm{ha}^{-1}$.

The average exportation rate was $1.7 \mathrm{~g} \mathrm{Cu}$ per tonne/grain, lower than the ones found in studies conducted in the USA. Bender et al. (2013) quantified the removal of $3.4 \mathrm{~g} \mathrm{t}^{-1} \mathrm{Cu}$ for production around $12.0 \mathrm{t} \mathrm{ha}^{-1}$, while Ciampitti and Vyn (2013) obtained a rate of $2.6 \mathrm{~g} \mathrm{t}^{-1}$.

To extract $\mathrm{Fe}$, a significant effect of hybrids and investment environments was observed in some of the phenological stages, with interaction between these factors only in the R6 stage. There were few differences between the studied hybrids in Fe extraction in the reproductive phase; DKB 310 exceeded the others in Fe extraction only in the R2 and R5 stages. This similar behavior among cultivars confirms Brown and Bell (1969), in which hybrids cultivated in soils with adequate $\mathrm{Fe}$ content tend not to express differences in the extraction of this micronutrient.

For the two fertilization environments, Fe extraction accentuated from the V7 stage (33 days after sowing) to the V12 stage (49 days after sowing). As observed for $\mathrm{Cu}, \mathrm{Fe}$ absorption lasted until physiological maturity (stage R6), completing 2,513 and 1,880 $\mathrm{g} \mathrm{ha}^{-1}$ in high and medium fertilization investment environments, respectively (Table 3, Figure 3). On average, up to the bolting stage (VT), 51\% maximum accumulation of Fe by maize was reached. Practically half of this micronutrient accumulation occurred due to uptake in the maturation and reproductive stages, differing from North American standards, in which more than two-thirds of extraction happened before flowering (Bender et al., 2013). 

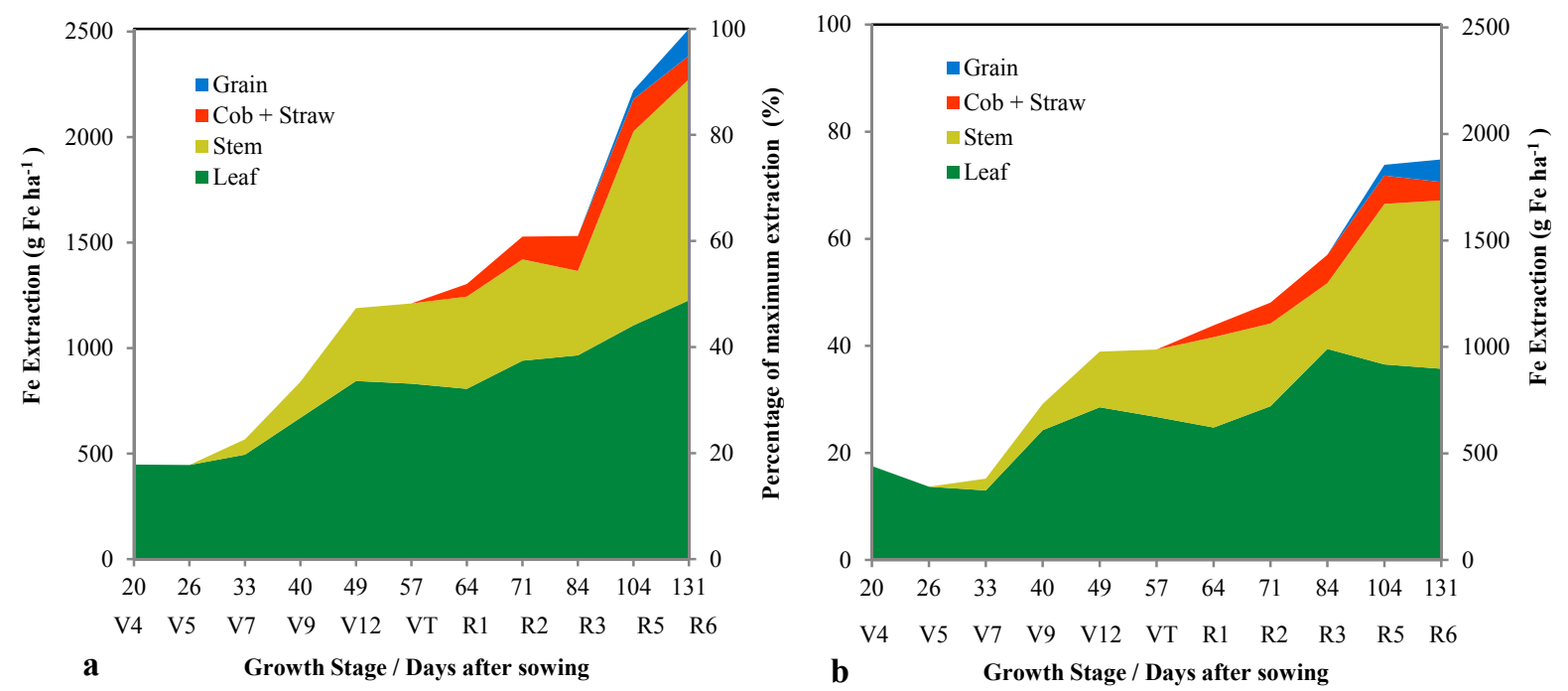

Figure 3. Iron uptake during maize cycle grown in environments with high (a) and medium (b) investment in fertilization. Average of four hybrids

Total Fe uptake data were close to 1,900 $\mathrm{g} \mathrm{ha}^{-1}$, value reported by Karlen et al. (1988), higher than the average of $1,100 \mathrm{~g} \mathrm{ha}^{-1}$ found by Bender et al. (2013) in a study with transgenic hybrids in the USA. However, this value is below the 3,296 $\mathrm{g} \mathrm{ha}^{-1}$ reported by Duarte et al. (2003) as the average of cultivars from temperate and tropical climate evaluated in Brazil. The patterns of $\mathrm{Fe}$ extraction by maize may be quite variable, according to environments, soil conditions, hybrids and other handling practices established in the crop.

The trend of Fe accumulation in physiological maturation in different parts of the plant was similar in both environments, with 48, 42,5, and 5\% distributed in leaf, stem, cob + straw and grains, respectively (Figure 3). Thus, leaves and stem are the main sites of Fe deposition absorbed by maize, while the grains do not represent a strong drain of this micronutrient. The surface liming $\left(2 \mathrm{t} \mathrm{ha}^{-1}\right)$, performed before the start of the experiment in the high investment environment, did not affect $\mathrm{Fe}$ acquisition by maize. This is consistent with the absence of significant alterations in $\mathrm{pH}$ data in soil analysis, although the available levels of Fe (Table 1) are interpreted as low and medium (Alvarez et al., 1999), in high and medium investment, respectively.

On average, for each tonne of grain, maize extracted 199 g Fe, close to Ciampitti \& Vyn (2013), which quantified absorption of $194 \mathrm{~g} \mathrm{t}^{-1}$. In spite of being the micronutrient extracted in greater quantity by maize plants (Table 3), Fe proportion allocated in the grains was relatively low, about $5.4 \%$ of the total extracted. This proportion corresponds to an exportation of $10.6 \mathrm{~g} \mathrm{t}^{-1}$, a rate lower than reported by Bender et al. (2013) and Ciampitti and Vyn (2013), of 20.7 and $32.3 \mathrm{~g} \mathrm{t}^{-1}$, respectively.

In the case of manganese (Mn), the extraction was influenced by the hybrids and fertilization environments in several stages from V5, including the evaluation performed in the physiological maturation (R6). However, there was no interaction between these factors. Among the hybrids, DKB 310 stood out in Mn accumulation, with significantly higher content than the other hybrids, especially at the end of the cycle, in the R5 and R6 stages. Similar to $\mathrm{Cu}$ and $\mathrm{Fe}$ extraction, when expressing the highest potential of dry mass and grain yield, DKB 310 hybrid also exhibited higher Mn requirement.

High investment environment in fertilization promoted greater Mn accumulation starting in V5; the total extraction in the physiological maturation was 778 and $500 \mathrm{~g} \mathrm{ha}^{-1}$ in the environments of high and medium investment, respectively (Table 3). These quantities are below the $900 \mathrm{~g} \mathrm{ha}^{-1}$ quantified by Karlen et al. (1988); however, close to the values obtained by Duarte et al. (2003) and Andrade et al. (1975b), of $638 \mathrm{~g} \mathrm{ha}^{-1}$ and 496 to $720 \mathrm{~g} \mathrm{ha}^{-1}$, respectively.

After Fe, Mn was the second micronutrient with the highest extraction by maize plants. The most expressive accumulation under high technological investment (Table 3, Figure 4) may be associated with the greater potential of dry mass production by hybrids (Table 2 ) in this condition. 

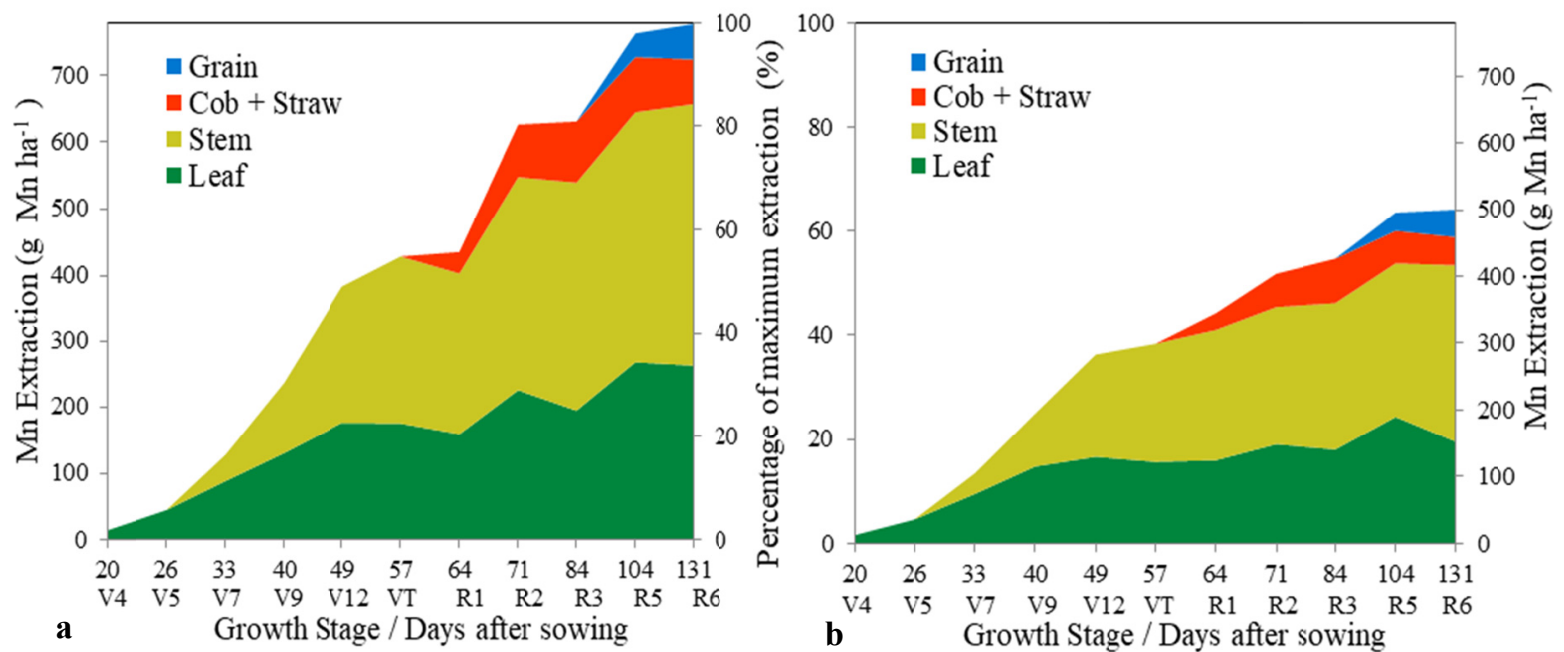

Figure 4. Manganese uptake during maize cycle grown in environments with high (a) and medium (b) investment in fertilization. Average of four hybrids

On average, up to the VT stage, $58 \%$ was the maximum accumulation of Mn by maize. In this study, Mn extraction pattern differed from the results of Karlen et al. (1988), which accounted for more than $70 \%$ of the total Mn uptake up to the R1 stage. Taking into account the intense extraction during the vegetative phase in the high investment environment (Figure 4), Mn supply at the earliest stages of the crop is a strategy to increase the use capacity of the plants. Nevertheless, the demand for the micronutrient persists until grain maturation.

At physiological maturation, the average proportion of Mn accumulation in the different parts of the plants was $32,51,9$ and $8 \%$ in leaf, stem, cob + straw, and grains, respectively, with higher contents in the vegetative parts, notably on the stem. According to Duarte et al. (2003), the stem represents the main compartment of Mn accumulation in the mature plant, acting as storage structure of this micronutrient.

For each tonne of maize grains, it was necessary for the plants to accumulate about $58 \mathrm{~g} \mathrm{Mn}$, close to $50 \mathrm{~g} \mathrm{t}^{-1}$ reported by Ciampitti and Vyn (2013). The harvest resulted in an average exportation rate of $4.3 \mathrm{~g} \mathrm{t}^{-1} \mathrm{Mn}$, lower than reported by Pauletti (2004), Bender et al. (2013), and Ciampitti and Vyn (2013), 6.5; 6.0 and $7.0 \mathrm{~g} \mathrm{t}^{-1}$, respectively.

Zinc extraction showed significant effects of hybrids from the VT stage to R6 and effects of fertilization environments in all the phenological stages (Table 3), but with no interaction between these factors. The DKB 310 hybrid has differentiated by higher accumulation values in the two final stages. Again, this differentiated nutritional demand seems to relate to its greater capacity of growth and grain production (Table 2). In the average of hybrids, there was a continuous increase in $\mathrm{Zn}$ extraction along the cycle until practically stabilizing in R5, reaching 486 and $396 \mathrm{~g} \mathrm{ha}^{-1}$ in the high and medium fertilization investment environments, respectively (Table 3 and Figure 5). 

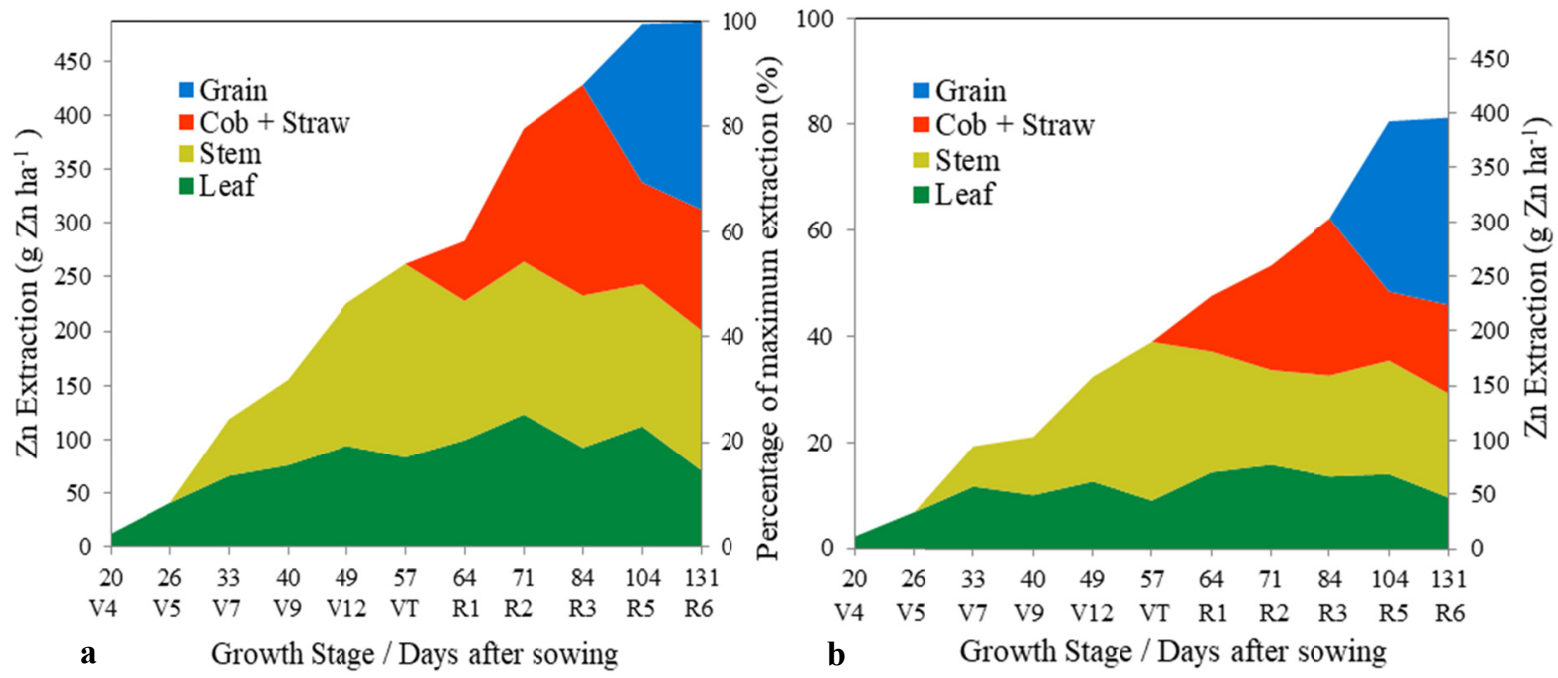

Figure 5. Zinc uptake during maize cycle grown environments with high (a) and medium (b) investment in fertilization

In average, up to bolting (VT), occurred $51 \%$ of total $\mathrm{Zn}$ uptake by the hybrids (Table 3), remaining half of $\mathrm{Zn}$ accumulation from flowering to maturation. This draws attention to the need for $\mathrm{Zn}$ availability conditions and soil humidity adequate for its acquisition at later periods, that is, at the reproductive crop stages. This result corroborates the pattern found by Bender et al. (2013) in which more than $70 \% \mathrm{Zn}$ was absorbed during the period of late vegetative growth and throughout the reproductive phase. This behavior reinforces the chances of response to $\mathrm{Zn}$ leaf applications between the end of the vegetative phase and the initial reproductive stages, due to the relatively high demand of this micronutrient for grain formation (Figure 5).

Between the R5 and R6 stages, $\mathrm{Zn}$ present in the leaves and stems was redistributed to the straw + cob and grains compartments. On average, in R5, the content partition was 20,27, 18 and 35\%, reaching physiological maturation (R6) with 13, 24, 21 and 42\% Zn allocated between the leaf, stem, straw + cob + grains, respectively (Figure 5).

The high investment environment was able to maintain higher proportions of $\mathrm{Zn}$ in other compartments of the plant relative to the grains, which constitute the preferential drain of the micronutrient in the maturation stage. Under high investment, the partition was 14, 25, 23 and 38\%, while in medium investment these proportions were 12, 23, 20 and $45 \% \mathrm{Zn}$ in leaf, stem, cob + straw, and grain, respectively (Figure 5). Therefore, under greater investment in fertilization, the need for internal redistribution of $\mathrm{Zn}$ was lower, allowing supplying the grain drain with less depletion of the reserves in the other compartments of the plant.

However, $\mathrm{Zn}$ targeting for the grains in the hybrids used in this study occurred in a magnitude significantly lower than $62 \%$ and $56 \%$ reported by Bender et al. (2013), and Karlen et al. (1988), respectively. According to some authors (Karlen et al., 1988; Heckman et al., 2003), the redistribution of the accumulated Zn can vary according to the agronomic management, productivity and concentration of nutrients in maize grains.

On average, to produce a tonne of maize, the plants extracted $40 \mathrm{~g} \mathrm{Zn}$, falling short of $55 \mathrm{~g} \mathrm{t}^{-1}$ reported by Ciampitti and Vyn (2013). With the grain harvest, the average exportation in the experimental conditions in Sete Lagoas, Minas Gerais, Brazil, was $16.5 \mathrm{~g} \mathrm{t}^{-1} \mathrm{Zn}$, lower than the rates of 29.0; 25.7; and $28.6 \mathrm{~g} \mathrm{t}^{-1}$ found by Pauletti (2004), Bender et al. (2013) and Ciampitti \& Vyn (2013), respectively.

Contrasting information from the literature, the uptake and exportation rates of $\mathrm{Cu}, \mathrm{Fe}, \mathrm{Mn}$ and $\mathrm{Zn}$ by maize are quite variable according to the experimental conditions, cultivars and the management practices applied to the crop. However, the values measured in this study tend to be lower than the ones of other studies with similar yield levels. This would indicate that cultivars currently used by Brazilian farmers show good conversion efficiency of these micronutrients on biomass and grains, making more efficient the use of fertilizers applied to the crops.

The differences in the extraction and export of micronutrients by the studied hybrids, in relation to the traditional literature indicators, reinforce the need for constant data updating, preferentially particularizing them for the 
different regions of maize cultivation. This approach should gain relevance as better results are sought in crops, especially in intensive production systems.

\section{Conclusions}

Micronutrient uptake is increased when a hybrid with higher potential for biomass production grows in an environment with greater supply of nutrients.

Micronutrient uptake persists throughout the maize cycle, including during the final stages of the reproductive phase, showing late demand for the crop. On average, after tasseling, about 39, 50, 42, and 49\% of the total $\mathrm{Cu}$, Fe, Mn and $\mathrm{Zn}$ absorption still occurs, respectively.

Total uptake of $\mathrm{Cu}, \mathrm{Fe}, \mathrm{Mn}$ and $\mathrm{Zn}$ are, respectively, around 8, 199, 58 and $40 \mathrm{~g}$ to produce a tonne of grain, from which $23,5,8$, and $42 \%$ are exported by the harvest.

Micronutrient uptake and exportation rates for the studied transgenic hybrids are lower than the ones previously reported in Brazil and in works abroad.

\section{Acknowledgements}

To CONACYT (Mexican National Council for Science and Tecnology) for granting the scholarship of the first author. To the Maize and Sorghum Research Center, CNPMS/EMBRAPA, for the facilities. To UFSJ for the opportunity.

\section{References}

Alvarez V. V. H., Novais, R. F., Barros, N. F., Cantarutti, R. B., \& Lopes, A. S. (1999). Interpretação dos resultados das análises de solos. In A. C. Ribeiro, P. T. G. Guimaraes, \& V. V. H. Alvarez (Eds.), Recomendação para o uso de corretivos e fertilizantes em Minas Gerais (pp. 314-315). Viçosa: Comissão de Fertilidade do Solo do Estado de Minas Gerais, Brazil.

Andrade, A. G., Haag, H. P., \& Oliveira, G. D. (1975a). Acumulação diferencial de nutrientes por cinco cultivares de milho (Zea mays L.). I. Acumulação de macronutrientes. Anais da Escola Superior de Agricultura "Luiz de Queiroz", 32, 115-149. Retrieved from https:/www.revistas.usp.br/aesalq/article/ viewFile/39083/41967

Andrade, A. G., Haag, H. P., Oliveira, G. D., \& Sarruge, J. R. (1975b). Acumulação diferencial de nutrientes por cinco cultivares de milho (Zea mays L.) II. Acumulação de micronutrientes. Anais da Escola Superior de Agricultura “Luiz de Queiroz”, 32, 151-171. https://doi.org/10.1590/S0071-12761975000100012

Bender, R. R., Haegele, J. W., Ruffo, M. L., \& Below, F. E. (2013). Nutrient uptake, partitioning, and remobilization in modern, transgenic insect-protected maize hybrids. Agronomy Journal, 105, 161-170. https://doi.org/10.2134/agronj2012.0352

Borges, I. D., Von Pinho, R. G., \& Pereira, J. L. A. R. (2009). Micronutrients accumulation at diferen-te maize development stages. Ciência e Agrotecnologia, 33, 1018-1025. https://doi.org/10.1590/S1413-705420090 00400011

Brown, J. C., \& Bell, W. D. (1969). Iron uptake dependent upon genotypes of corn. Soil Science Society of America Proceedings, 33, 99-101. https://doi.org/10.2136/sssaj1969.03615995003300010027x

Castoldi, R., Charlo, H. C. O., Vargas, P. F., \& Braz, L. T. (2009). Crescimento, acúmulo de nu-trientes e produtividade da couve-flor. Horticultura Brasileira, 27, 438-446. https://doi.org/10.1590/S0102-0536 2009000400007

Ciampitti, I. A., \& Vyn, T. J. (2013). Maize Nutrient Accumulation and Partitioning in Response to Plant Density and Nitrogen Rate: II. Calcium, Magnesium, and Micronutrients. Agronomy Journal, 105, 1645-1657. https://doi.org/10.2134/agronj2012.0467

Ciampitti, I. A., \& Vyn, T. J. (2014). Understanding Global and Historical Nutrient Use Efficiencies for Clos-ing Maize Yield Gaps. Agronomy Journal, 106, 1-11. https://doi.org/10.2134/agronj14.0025

Coelho, A. M., \& França, G. (1995). Nutrição e adubação: seja doutor do seu milho. Arquivo do Agrônomo, 2, $1-9$.

Coelho, A. M., \& Resende, A. V. (2008). Exigências nutricionais e adubação do milho safrinha (Circular Técnica 111, p. 10). Ministério da Agricultura Pecuária e Abastecimento. Retrieved from https://ainfo.cnptia. embrapa.br/digital/bitstream/CNPMS-2009-09/21379/1/Circ_111.pdf 
Duarte, A. P., Kiehl, J. C., Camargo, M. A. F., \& Reco, P. C. (2003). Acúmulo de matéria seco e nutriente em cultivares de milho originaria de clima tropical e introduzido de clima temperado. Revista Brasileira de Milho e Sorgo, 2, 1-20. https://doi.org/10.18512/1980-6477/rbms.v2n03p\%25p

EMBRAPA (Empresa Brasileira de Pesquisa Agropecuária). (2013). Centro Nacional de Pesquisa de Solos. Sistema brasileiro de classificação de solos (p. 353). Rio de Janeiro, Brazil. Retrieved from http://livimagens.sct.embrapa.br/amostras/00053080.pdf

Ferreira, C. F. (2009). Diagnose nutricional de diferentes cultivares de milho (Zea mays L.) de diferentes niveis tecnológicos (p. 114, Dissertação, Mestrado em Ciências do Solo, Setor de Ciências Agrárias, Universidade Federal do Paraná, Curitiba). Retrieved from https://acervodigital.ufpr.br/bitstream/handle/1884/18372/ Diagnose\%20nutricional\%20de\%20cultivares\%20de\%20milho\%20(Zea\%20mays\%20L.)\%20de\%20difere ntes\%20niveis\%20tecnologicos.pdf?sequence $=1$

Ferreira, D. F. (2011). Sisvar: A computer statistical analysis system. Ciência e Agrotecnologia, 35, 1039-1042. https://doi.org/10.1590/S1413-70542011000600001

Heckman, J. R., Sims, J. T., Beegle, D. B., Coale, F. J., Herbert, S. J., Bruulsema, T. W., \& Bamka, W. J. (2003). Nutrient Removal by Corn Grain Harvest. Agronomy Journal, 95, 587-591. https://doi.org/10.2134/ agronj2003.5870

Hiroce, R., Furlani, A. M. C., \& Lima, M. (1989). Extração denutrientes na colheita por populações e híbridos de milho (Boletim científico, 17, p. 24). Campinas: Instituto Agronômico.

Karlen, D. L., Flannery, R. L., \& Sadler, E. J. (1988). Aerial accumulation and partitioning of nutrients by corn. Agronomy Journal, 80, 232-242. https://doi.org/10.2134/agronj1988.00021962008000020018x

Lorenz, A. J., Gustafson, T. J., Coors, J. G., \& De Leon, N. (2010). Breeding maize for a bioeconomy: A literature survey examining harvest index and stover yield and their relationship to grain yield. Crop Science, 50, 1-12. https://doi.org/10.2135/cropsci2009.02.0086

Padilha, F. A., Resende, A. V., Moreira, S. G., Guimarães, L. J. M., Guimarães, P. E. O., \& Oliveira, A. C. (2015). Produtividade de híbridos de milho sob dois níveis de tecnologia na região central de Minas Gerais. Revista Brasileira de Milho e Sorgo, 14, 207-218. https://doi.org/10.18512/1980-6477/rbms.v14n2p207-218

Pauletti, V. (2004). Nutrientes: Teores e interpretações (2nd ed., pp. 25-27). Castro: FUNDAÇÃO ABC.

Ritchie, S. W., Hanway, J. J., \& Benson, G. O. (2003). Como a planta de milho se desenvolve (Informações Agronômicas, 103, p. 20). Piracicaba: Potafos.

Silva, C. S. (2009). Manual de análises químicas de solos, plantas e fertilizantes (p. 627). Brasília: Embrapa Informação Tecnológica.

Vasconcellos, C. A., Barbosa, J. V. A., Santos, H. L., \& França, G. E. (1983). Acumulação de massa seca e de nutrientes por dois híbridos de milho com e sem irrigação suplementar. Pesquisa Agropecuária Brasileira, 18, 887-901. Retrieved from https://seer.sct.embrapa.br/index.php/pab/article/view/15389

\section{Copyrights}

Copyright for this article is retained by the author (s), with first publication rights granted to the journal.

This is an open-access article distributed under the terms and conditions of the Creative Commons Attribution license (http://creativecommons.org/licenses/by/4.0/). 